African Crop Science Journal by African Crop Science Society is licensed under a Creative Commons Attribution 3.0 Uganda License. Based on a work at www.ajol.info/ and www.bioline.org.br/cs DOI: http://dx.doi.org/10.4314/acsj.v25i1.5S

\title{
MEMBERSHIP TO INNOVATION PLATFORMS AND GENDER IN OWNERSHIP OF PRODUCTIVE ASSETS IN THE SAVANNAS OF WEST AFRICA
}

\author{
A. AYANWALE, A. ADEKUNLE ${ }^{1}$, A.O. FATUNBI ${ }^{1}$, L. OLARINDE ${ }^{2}$ and C. ADELEKUN \\ Department of Agricultural Economics, Obafemi Awolowo University, Ile-Ife, Nigeria \\ ${ }^{1}$ Forum for Agricultural Research in Africa,Accra, Ghana \\ ${ }^{2}$ Department of Agricultural Economics, LadokeAkintola University of Technology, Ogbomoso, Nigeria
}

Corresponding author: aayanwa@yahoo.co.uk

\begin{abstract}
Access to productive assets is a major issue in the gender empowerment discourse. Asset accumulation is a precondition for economic empowerment, and sustainable accumulation of assets is key to upward mobility beyond survival, and towards economic empowerment. The objective of this study was to examine the role that participation in the Integrated Agricultural Research for Development (IAR4D)'s Innovation Platform "IP" (social capital) play in empowering rural women to acquire productive assets using the case of the sub-Saharan Africa Challenge Programme (SSA-CP). We utilised panel data from baseline and midline data obtained from the Kano-Katsina-Maradi Pilot Learning Site (KKM PLS) of the SSA CP in West Africa. The data were obtained from twelve IPs of the three Task Forces (TFs) that made up the KKM PLS of the SSA CP. Altogether, the analysis involved 600 households in the PLS. Both descriptive analysis and the probit regression models showed that women who were inferior to men in productive asset ownership at the inception of the project improved with participation in the innovations of the project, in terms of human asset, input resource, durable business asset and household good.The value of women's asset index was 21.78 compared to that of men at 18.33 at the end of the project. Probit regression results suggest that membership to IP, female education level, age of female spouse and household size are determinants of asset ownership by women in the study area. The results confirm that social capital in the form of membership of IP enhances accumulation of productive assets for women.
\end{abstract}

Key Words: Asset ownership, gender empowerment, innovation platform

\section{RÉSUMÉ}

L'accès aux ressources de production est un problème majeur dans les discours sur l'autonomisation des femmes. L'accumulation des biens est un pré-requis pour l'autonomisation économique, et l'accumulation durable des biens est éssentielle pour une mobilité sociale au delà de la subsistance, et pour une automisation économique. L'objectif de cette étude était d'examiner le rôle que la participation à la Plate-forme d'Innovation "IP" en Recherché Agricole Intégrée pour le Développpement (IAR4D)- (Capital social) joue dans l'automisation des femmes en milieu rural pour acquérir des biens de production en se basant sur le cas du programme des défis de l'Afrique Sub-Saharienne (SSA-CP). Nous avons utilisé les données de base et les données de la ligne médiane venues du site Pilot d'apprentissage de Kano-Katsina-Maradi (KKMPLS) de SSA en Afrique de l'Ouest. Les données étaient obtenues des douze IPs des trois groupes de travail (TFs) qui formaient les KKMPLS de SSA CP. Ensemble, l'analyse implique 600 ménages dans les PLS. L'analyse descriptive et les modèles de régression de Probit à la fois ont montré que les femmes qui étaient inférieures aux hommes dans l'accès aux ressources de production au début du projet se sont vues améliorées avec la participation aux innovations du projet, en termes 
des ressources humaines, intrants, actif commercial durable et bien familial. La value de l'indice d'accès aux biens des femmes était 21,78 comparée à celle des hommes qui était de 18,33 vers la fin du projet. Les résultats de la régression de Probit suggèrent que l'appartenance à l'IP, le niveau d'éducation de la femme, l'âge de la femme et la taille du ménage sont les déterminants d'accès aux propriétés par les femmes dans le mileu d'étude. Les résultats confirment que le capital social en forme d'appartenance aux IP augmente l'accumulation des propriétés productives des femmes.

Mots Clés: Accès à la propriété, l'autonomisation de la femme, plate-forme d'innovation

\section{INTRODUCTION}

Access to productive assets is a major issue in the gender empowerment discourse.Asset accumulation is a pre-condition for economic empowerment, and sustainable accumulation of assets is key to upward mobility beyond survival, and towards economic empowerment (ZoRandriamaro, 2008).Women's economic empowerment, that is, their capacity to bring about economic change for themselves, is increasingly viewed as the most important contributing factor to achieving equality between women and men (Ogato et al., 2009). Economic empowerment can happen only when women are able to accumulate and sustain assets in relation to income, consumption and production (Njuki and Sanginga 2013).

Friedemann-Sanchez (2006) showed that women in the cut the flower industry of Columbia utilised the wage income received from their employment and gained self-worth to put in motion the social, physical, financial, and human assets they hold to easily access high-paying positions, accumulate wealth, and buy property. These assets empowered women in conceiving, assessing, and exercising intrahousehold bargaining strategies in challenging patriarchal household culture, as well as escaping from domestic violence.

Hence, economic empowerment involves movements and transitions out of poverty, with asset building thresholds in terms of physical, human, social, financial and ecological capital. Growing evidence shows that the distribution of individuals' ownership and control of assets within a household can present important implications on women's empowerment
(Randriamaro, 2009). In Ghana, women's asset ownership increases the budget share spent on food and education (Doss, 2006). According to Beegle et al. (2001), in Indonesia, wife's perception of her share of assets owned by her and her husband is associated with obtaining prenatal care. Hashemi et al. (1996) have found that intervention programmes in Bangladesh have had significant effects on a variety of measures of women's empowerment, including mobility, economic security, control over income and assets, political and legal awareness, and participation in public protests and political campaigning.

The International Centre for Research on Women (ICRW, 2010) noted that when women farmers access resources, their productivity increases, and this enhances the food security status of their families. When women own property and earn money from it, they may have more bargaining power at home. This in turn can help reduce their vulnerability to domestic violence and other unhealthy relations (Jetti, 2006). Access to time-saving technologies enhances the economic benefits accruing to women such as increasing their productivity as well as the opportunity to engage in off-farm income generating enterprises (Grassi et al., 2015).

Working with groups is a major mechanism through which development programs can enable women to increase their control of assets, improve their productivity, and enhance their status and well-being. In fact, the networks and collective action that groups generate are recognised as assets in themselves. (Kumar and Quisumbing, 2010). According to the Gender, Agriculture and Assets Project 
(GAAP, 2013) of the International Food Policy Research Institute (IFPRI), "social capital" is an intangible asset that can be converted into marketable connections and skills.

Friedemann-Sanchez (2006) demonstrated how social capital in terms of kin and labourrelated network facilitates the acquisition of productive assets among women in Colombia. Studies usually measure social capital, by the number of local associations a household is a member to and that it is an important factor in empowerment (Nega et al., 2009). However, social capital goes along with significant gender differences inpatterns of social organisation. It also takes a centre stage in empowerment efforts because it has the greatest bearing upon power relations in a society and, thus on the prospect of empowerment (Nega et al., 2010).

Conceptual traditions agree that social capital is not a single entity, but is rather multidimensional in nature, most frequently defined in terms of the groups, networks, norms and trust that people have available to them for productive purposes. Literature has yielded two basic concepts. The first refers to the resources (such as information, ideas, support) that individuals are able to procure by virtue of their relationships with other people. These resources ("capital") are "social" in that they are only accessible in and through these relationships. They are unlike physical (tools, technology) or human (education, skills) capital which are essentially the property of individuals (Burt, 2000).

The second and more common approach to social capital refers to the nature and extent of one's involvement in various informal networks and formal civic organisations. Social capital inthis sense is used as a conceptual term to characterise the many and varied ways in which a given community's members interact (Grootaert et al., 2004).

The objective of this paper therefore is toexamine the role that participation in the IAR4D's Innovation Platform "IP" - (social capital) has played in empowering the women to acquire productive assets that guarantees their households food security.

\section{METHODOLOGY}

The Sub-Saharan Africa Challenge Programme (SSA-CP). The SSA-CP was initiated in 2004 following extensive consultations with numerous agricultural stakeholders. The stakeholders counsulted included researchers, extension and development agents, policy makers, farmers and the private sector to diagnose the reasons behind the underperformance of agricultural research in Africa (FARA, 2006). The consultations proposed an alternative approach that aims to appropriately embed agricultural research within a larger system of innovation; whereby knowledge from numerous sources (comprising all various actors and stakeholders) is integrated and effectively put into use. This approach to agricultural research is termed Integrated Agricultural Research for Development (IAR4D) and has been adopted by the SSA-CP.

The SSA-CP's research wasorganised around four projects: One Meta-Analysis project and three Pilot learning site (PLS) projects in three different regions of subSaharan Africa (i.e., Lake Kivu (LK) in Eastern and Southern Africa, Kano-Katsina-Maradi (KKM) in West Africa, and ZimbabweMalawi-Mozambique (ZMM) in Southern Africa). Each Pilot Learning Sites (PLS) project comprised of three sub-projects.

The present study focused on the KKM. The three sub-projects that constituted the KKM project were distinguished by the agroecological zones (AEZs) where their research was based and focused. The relevant AEZs were the Sahel, the Sudan Savanna, and the Northern Guinea Savanna. Each of the three sub-projects aimed at evaluating the effectiveness of the IAR4D concept in its respective AEZ, by establishing Innovation Platforms (IPs) and conducting action research aimed at intensifying crop and 
livestock systems, improving access to markets, and promoting sustainable management of the natural resource base.Each of the three sub-projects had the same type of outputs, but activities differed based on the entry points and the specific context of each AEZ. The specificity of each sub-project came from the actual content of the field research work planned based on the identified entry points.

Data collection. The data were obtained through a household survey conducted during 2008 and 2011. The baseline data were collected between March and September 2008; while the midline data were between February and May 2011. The main instruments for data collection were structured questionnaires, administered to household heads by trained enumerators. Altogether, eight local government areas (LGAs) were covered for the purpose of data collection in each Taskforce (TF). Taskforce is an agglomeration of IPs, with each IP covering five villages within a local government.

This study, in line with the SSA-CP research method, employed multistage stratified random sampling within the selected local government areas (IAR4D and counterfactual) to select the villages where IAR4D were introduced. Study village communities where conventional approaches were in operation, and study villages where no agricultural interventions were carried out over the last 2-5 years, were taken as counterfactuals as opposed to the treatment villages. Selection of households in each of these villages was genderised in the sense that at least 30 percent of the households were female headed.

For each IP and its counterfactuals, innovation development, knowledge increase, and information sharing among IP members were monitored and assessed. This was achieved by documenting the number of meetings, as well as the information disseminated to members through these meetings. Furthermore, for each IP, information sharing and technology uptake within the communities were assessed using a stratified random sample of 10 farmers per village out of which three were female. The total sample size was, therefore 600 households per TF, giving a total of 1800 households in all.

Data analysis. The data collected were analysed using both descriptive and inferential statistical and econometric tools. The quantitative data were analysed with descriptive statistics including proportions, comparison of means as well as graphs. The asset indices for different assets were developed following the method of the Bill and Melinda Gates Foundation (2010), for the evaluation of their agriculture programmes. The asset index was calculated for all movable assets, including livestock (Eq. 1). Each of the asset was assigned a weight(ù) and then adjusted for age. The weight was calculated based on the value of the asset compared across the taskforce boundaries. Conscious efforts were made to document ownership of the various assets within the households by gender.

This ensures that assets that are of the same value are accorded the same weight, despite country or location differences in prices.

Household Domestic Asset Index (HDAI) = $\sum_{g=1}^{G}\left[\sum_{i=1}^{N}\left(\omega_{\mathrm{gi}} \mathrm{xa}\right)\right] \ldots \ldots \ldots \ldots .$. Equation 1

Where: $i=1,2, \ldots N ; g=1,2 \ldots . . G, \omega_{g i}$ is weight of the ith item of asset $\mathrm{g} ; \mathrm{N}=$ number of asset g owned by household; $a=$ age adjustment to weight; $G=$ number of assets owned by household.

As stated earlier, "social capital" was conceptualiased as membership of an IP which confers on the recipient some advantages. These are in terms of networking, easier access to productive inputs, assured markets among others. All of these are expected to enhance the productivity and income of the IP members and, thereby ultimately enable 
(empower) them to build more asset base than non-members. The various advantages enjoyed through membership were categorised by gender and descriptively discussed in the results.

Probit analysis. Binary probit regression analysis was used to estimate the probability that either the women in the household owned asset or not. In this case, the dependent variable took the form of a binary variable:

$1=$ women in the household owned asset; and $0=$ women in the household did not own asset.

The probit model took the form:

$$
P_{\gamma}(\gamma=1 \mid X)=\theta\left(X^{\prime} \beta\right)
$$

Where: $P_{\gamma}$ denotes the probability of women owning or not owning an asset (1 or 0 );

$\mathrm{X}$ is a vector of regressors on the spouse's and household characteristics;

$\theta$ is the cumulative distribution function (CDF) of the standard normal distribution; and $\beta$ is a parameter typically estimated by maximum likelihood.

\section{RESULTS AND DISCUSSION}

Table 1 shows the level of ownership of assets by gender in the KKM of West Africa after the project. In terms of the quantum of assets, the results show that women acquired more than men in five of the items viz: human assets, motorcycle, sprayer, sewing machine and chairs. In terms of human assets, both male and female employed at least five people in their enterprise; however, the size of human assets available to women (5.37) were more than that available to men (5.05). As for transport assets, women had more motorcycles (1.77) than men (1.64) (Table 1), signifying the possible preference of women for motorcycles as an asset.

Other assets which women had more than men were sprayers, sewing machines and chairs. A priori, sprayer is an asset that is usually jointly owned (Quisumbing et al., 2015) or exclusively owned by the male (Lay 2012, UN-women UNDP-UNEP PEI and World Bank, 2015). This shift in paradigm could be attributed to the capability built from learning and knowledge sharing from research entry point such as the promotion of appropriate integrated pest management (IPM) which is one of the key element of KKM taskforce. This has led to the "gendering" of tasks such that spraying is considered as a less arduous task which women may carry out. Larrea and Maldonado (2005), Oxfam (2007), Julia and White (2010) observed this gendering of tasks in cut flower industry in Latin America, on Malaysia plantation and in Kalimantan, Borneo.

Sewing machines are naturally believed to be women's in most developing countries (Guillen, 2013). For example, Guillen (2013) regards sewing machine as productive/ business assets generating future incomes for owners (Antonopoulos and Floro, 2005).

The women acquired more household durable asset, such as chairs, than the men. Household's durable assets such as chair reflect wealth and potential for long term consumption and spending (Blattman, 2013). Geetha (2016), while working in Karnataka, India found that sericulture women acquired household durable assets such as chairs after participating in self-help group.

In terms of overall asset index, the value of women's asset index (21.78) was also more than that of men (18.33) (Table 1), suggesting that women involved in this project did not perform poorly in terms of overall asset index. The changes in social asset ownership by gender in the KKM SSA-CP area are presented in Table 2. Evidently, women asset ownership increased more than for men in five items viz: human assets, ox plough, draft donkey, chairs and overall asset index. These results reveal a greater impact of the component of the promotion of labour saving devices e.g. traction on the asset accumulation of the 
TABLE 1. Amount and percentage asset ownership by gender in the KKM PLS in West Africa

\begin{tabular}{lrr}
\hline Asset & Male $\mathrm{n}=1385$ & Female $\mathrm{n}=411$ \\
\hline Human assets & $5.05(95.63)$ & $5.37(96.24)$ \\
Bicycle & $1.85(44.44)$ & $1.15(54.74)$ \\
Car & $1.48(10.15)$ & $1.17(14.11)$ \\
Motorcycle & $1.64(46.91)$ & $1.77(55.23)$ \\
& & \\
Farm equipment (asset) & Male $\mathrm{n}=1385$ & Female $\mathrm{n}=411$ \\
& & \\
Hoes, cutlasses & $21.88(98.09)$ & $10.29(91.48)$ \\
Ox plough & $1.83(30.15)$ & $0.64(21.16)$ \\
Wheel barrow & $1.65(24.83)$ & $1.40(37.71)$ \\
Water pump & $1.64(10.23)$ & $1.57(16.79)$ \\
Sprayer & $1.38(19.03)$ & $1.51(28.47)$ \\
34Tractor & $1.15(1.36)$ & $1.10(2.86)$ \\
Draft donkey & $1.94(4.02)$ & $1.72(2.91)$ \\
Draft cattle & $2.19(29.19)$ & $2.10(28.47)$ \\
Farm equipment & $4.49(29.54)$ & $4.18(25.55)$ \\
& & \\
Household asset holding & Male $\mathrm{n}=1385$ & Female $\mathrm{n}=411$ \\
Paraffin stove & & \\
Sewing machine & $2.04(27.79)$ & $1.94(33.58)$ \\
Mobile phone & $1.15(40.44)$ & $1.88(26.28)$ \\
Radio & $2.63(56.71)$ & $1.83(39.17)$ \\
Television & $3.77(85.61)$ & $2.93(81.02)$ \\
Chair & $2.26(22.79)$ & $1.54(31.38)$ \\
Asset index & $4.81(46.76)$ & $6.43(49.14)$ \\
\hline
\end{tabular}

*Figures in brackets are the percentage frequencies

women compared to the men. Promotion of appropriate labour saving devices was one of the research entry point of the KKM innovation platform. Use of traction animals and equipment reduces the drudgery associated with farming activities for the women (Bwalya and Akombelwa, 1999). Increase in human asset may imply the employment of additional labour for farming activities. The acquisition of draft cattle and the employment of more labour may be due to the intensification of croplivestock production. In another context, for example Ethiopia (Amare, 2002), female owners of ox-plough stated the need to employ males to operate the ploughs. Incidentally, the sixth asset which was also statistically significant was ownership of a car which is preferred by men, suggesting that men have resources to procure more expensive assets.

Results for social capital, as a factor in the ownership of assets due to membership of an IP, are presented in Table 3. In all, the membership of the IP enabled the participant to own more units of the twelve items of assets than non-members. Critical items included human assets, which suggests that membership enabled them to engage more able hands on their enterprises. This could be because of the capacity building facilitation that is available in the IP, where members are empowered in terms of easier access to productive inputs, as well as innovative ideas that pushes their productive frontier upwards. This finding confirms the assertion of Njuki 
TABLE 2. Percentage change in asset ownership by gender among members of KKM PLS in West Africa

\begin{tabular}{lccc}
\hline Asset & Malen=1385 & Femalen=411 & Student's T-value \\
\hline Human assets & 38.74 & 39.84 & $1.54^{*}$ \\
Bicycle & 2.8 & 6.3 & 1.03 \\
Car & 138.71 & 23.16 & $-1.94^{* *}$ \\
Motorcycle & 19.71 & 37.21 & 0.92 \\
& & & \\
Farm equipment (asset) & Malen=1385 & Femalen=411 & Student's T-value \\
& & & \\
Hoes, cutlasses & 134.62 & 35.27 & 1.35 \\
Ox plough & 13.66 & 32.83 & $2.13^{* *}$ \\
Wheel barrow & 29.92 & 8.53 & 0.97 \\
Water pump & 1.64 & 1.57 & -0.41 \\
Sprayer & 1.38 & 1.51 & 1.02 \\
Tractor & 1.15 & 1.10 & -0.16 \\
Draft donkey & 76.92 & 65.32 & 1.14 \\
Draft cattle & 3.19 & 48.09 & $2.07^{* *}$ \\
Farm equipment & 4.49 & 4.18 & -0.76 \\
& & & \\
Household asset holding & Malen=1385 & Femalen=411 & \\
& & & Student's T-value \\
Parafin stove & 2.04 & 1.94 & -0.53 \\
Sewing machine & 29.45 & 37.88 & 1.31 \\
Mobile phone & 68.59 & 57.92 & 1.28 \\
Radio & 42.11 & 11.41 & 1.31 \\
Television & 54.79 & 67.09 & 1.14 \\
Chair & 4.81 & 6.43 & $3.53^{* * *}$ \\
Asset index & 18.33 & 21.78 & $3.39^{* * *}$ \\
\hline & & &
\end{tabular}

$*, * *, * * *$ means significance at 10,5 and $1 \%$, respectively

and Sanginga (2013) that "women's membership in groups facilitates access to assets that they would otherwise not be able to access or own as individuals".

Other items were the transport assets such as a car, motorcycle and bicycle (Table 3). This suggests the vital importance of these assets in facilitating the movement of inputs from agro-dealers and outputs to the markets and ultimately boosting the income of the members. This significance of wheel barrows as an asset was also justified along this premise. While the significance of hoes, cutlasses and axes was suggestive of the fact that membership confers easier access to these vital assets and also that most of the respondents were smallholder farmers still using these assets.
One of the advantages of "social capital" is the facilitation of information among members. This is evident from the result that ownership of mobile phones, radio and television is statistically significant (Table 3). This confirms that members took sharing of information seriously. This is in conformity with the findings of Amarante and Vigorito (2009), who illustrated how the build-up of social capital improves access to resources such as credit, information and knowledge about new technology options and practices.Social networks and social relationships facilitate technology dissemination by expanding the choices available to each household member and influencing the distribution of benefits from the technology. 
TABLE 3. Percentage change in asset ownership by membership

\begin{tabular}{lccc}
\hline Asset & Membersn=440 & Non-membersn=1040 & Students' T-value \\
\hline Human Assets & 16.06 & 8.27 & $3.09^{* * *}$ \\
Bicycle & 16.86 & 6.28 & $1.70^{* *}$ \\
Car & 90.54 & 31.18 & $2.76^{* * *}$ \\
Motorcycle & 17.45 & 10.56 & $2.29^{* * *}$ \\
& & & Student's T-value \\
Farm equipment (asset) & Membersn=440 & Non-membersn=1040 & $1.61^{* *}$ \\
& & & 0.320 \\
Hoes, cutlasses & 150.65 & 63.16 & $2.40^{* * *}$ \\
Ox Plough & 25.46 & 7.15 & 0.10 \\
Wheel barrow & 16.99 & 8.39 & 0.21 \\
Water pump & 11.64 & 11.66 & 0.32 \\
Sprayer & 12.38 & 13.51 & 0.40 \\
Tractor & 14.15 & 14.10 & 0.26 \\
Draft donkey & 412.82 & 236.54 & 0.23 \\
Draft cattle & 28.24 & 15.34 & \\
Farm equipment & 4.30 & 4.25 & Student's T-value \\
& & & \\
Household asset holding & Membersn=440 & Non-membersn=1040 & 0.44 \\
Parafin stove & & & $2.43^{* * *}$ \\
Sewing machine & 25.04 & 21.94 & $2.93^{* * *}$ \\
Mobile phone & 35.38 & 18.43 & $1.70^{* *}$ \\
Radio & 78.74 & 20.28 & $1.83^{* *}$ \\
Television & 47.55 & 39.52 & $3.63^{* * *}$ \\
Chair & 51.12 & 30.53 & \\
Asset index & 51.49 & 50.95 & 4.13 \\
\hline
\end{tabular}

$*, * *, * * *$ means significance at 10,5 and $1 \%$, respectively

Factors influencing ownership of productive assets. Table 4 presents the factors that influenced ownership of assets among households (Table 4) and by women (Table 5) involved in the KKM IPs in West Africa. The results are generally robust and consistent with the a-priori expectations. At the household level (Table 4), membership to IP was one of the significant factors that influenced ownership of assets. Further analysis (Table 5) shows that there was 17.4 percent probability that women who belonged to an IP will acquire more productive assets. This is consistent with the a priori expectation, and means that social capital positively induces increased acquisition of productive assets for better livelihood. For example, Njuki and
Mburu (2013) found that membership to group in Kenya encouraged women to increase their livestock asset.

The marginal effect of the probit regression analysis (Table 4) shows that there was a 49 percent probability of households increasing their assets by belonging to the IP. This result is consistent with that of Kumar and Quisumbing (2010) in Bangladesh, who found that the probability of increasing assets was higher when a group approach was used than when an individual approach was used. The probability of increasing asset ownership was 43.5 percent in the Sudan Savanna taskforce as opposed to 34.9 percent in the NGS taskforce. The same was found in Table 5 where the probability of women owning 
TABLE 4. Results of probit regression of factors influencing household's ownership of assets among members of KKM PLS in West Africa

\begin{tabular}{lll}
\hline Variable & Coefficients & Marginal effect \\
\hline Households owns Asset (yes=1; no=0) & & \\
& & \\
Age of spouse & $-0.011(0.003)^{* * *}$ & $-0.004(0.001)^{* *}$ \\
Education of spouse & $-0.036(0.014)^{* * *}$ & $-0.145(0.005)^{* * *}$ \\
Household size & $-0.031(0.007)^{* * *}$ & $-0.012(0.002)^{* * *}$ \\
Farming experience (years) & $-0.007(0.003)^{* * *}$ & $-0.003(0.001)^{* * *}$ \\
Asset index(baseline) & $0.000(0.002)$ & $0.000(0.001)$ \\
Membership of group (Yes=1) & $0.126(0.085)^{*}$ & $0.491(0.033)^{*}$ \\
Food security index & $-0.031(0.008)^{* * * *}$ & $-0.012(0.003)^{* * *}$ \\
Sudan TF & $-1.163(0.100)^{* * *}$ & $-0.435(0.036)^{* * *}$ \\
NGS TF & $-0.906(0.098)^{* * *}$ & $-0.349(0.036)^{* * *}$ \\
Gender (male=1; female=0) & $-0.072(0.095)$ & $-0.028(0.037)$ \\
Constant & $2.215(0.218)^{* * *}$ & \\
Number of observations & 1309 & \\
DF & 1308 & \\
Log likelihood & -750.128 & \\
Chi square $(7)$ & $302.06 * * *$ & \\
\hline
\end{tabular}

****** means significant at $5 \%$ and $1 \%$ respectively. *Figures in brackets are the standard errors. Source:Data Analysis 2014

TABLE 5. Results of probit regression of factors influencing women's ownership of assets among members of KKM PLS in West Africa

\begin{tabular}{lll}
\hline Variable & Coefficients & Marginal effect \\
\hline Women owns asset (yes=1; no=0) & & \\
& & \\
Age of spouse & $-0.012(0.007)^{* * *}$ & $-0.004(0.002)^{* *}$ \\
Education of spouse & $-0.084(0.032)^{* * *}$ & $-0.030(0.011)^{* * *}$ \\
Household size & $-0.036(0.016)^{* * *}$ & $-0.013(0.005)^{* * *}$ \\
Farming experience (years) & $0.008(0.007)$ & $-0.002(0.002)$ \\
Asset index (baseline) & $0.002(0.004)$ & $0.000(0.001)$ \\
Membership of group (Yes=1) & $0.473(0.195)^{* * *}$ & $0.174(0.073)^{* * *}$ \\
Food security index & $-0.010(0.022)$ & $-0.004(0.008)$ \\
SudanTF & $-1.335(0.290)^{* * *}$ & $-0.493(0.094)^{* * *}$ \\
NGS TF & $-1.244(0.274)^{* * *}$ & $-0.435(0.085)^{* * *}$ \\
Constant & $2.557(0.503)^{* * *}$ & \\
Number of observations & 244 & \\
DF & 243 & \\
Log likelihood & -141.721 & \\
Chi square(9) & $63.60 * * *$ & \\
\end{tabular}

**;*** means significant at 5\% and 1\% respectively. *Figures in brackets are the standard errors. Source: Data Analysis 2014 
productive assets in the Sudan savanna taskforce (49.3) was higher than that of the NGs taskforce (43.5).

Age and educational level of spouse, household size, and location of the household in terms of the taskforce they belong to also significantly influenced women's ownership of assets (Table 5). In the household (Table 4), in addition to the aforementioned factors, years of farming experience and food security index influenced the acquisition of assets. Generally, however, the marginal effects show lower probability than the results obtained for the household, thus suggesting the overarching influence of household membership on asset acquisition.

\section{CONCLUSION}

Membership in the KKM-PLS of West Africa encourages increased ownership of productive asset by women more than men. There is some level of gender bias to ownership of some item of assets as expensive assets such as cars are owned by men; while less expensive and domestic assets such as chairs are owned by women. However, asset accumulation is higher among women than men. Higher probability of increased ownership of productive assets by the household compared to that of women as an individual, suggest the overwhelming influence of the household on the probability of owning productive asset by the respondents. In essence, to get more women to own productive assets, it would be more effective to engineer the mobilisation using household well-being as the point of advocacy. The study has established the importance of membership of an IP as a "social capital" and affirms that the use of the IAR4D template is quite effective in mobilising members to acquire productive assets. The study concludes that social capital do empower households especially women in the KKM of the SSA-CP.

\section{ACKNOWLEDGEMENT}

The authors acknowledge the financial support of the SSA-CP of FARA for this study. The ObafemiAwolowo University, Ile-Ife provided materials for the study.

\section{REFERENCES}

Amarante, V. and Vigorito, A. 2009. CCTs,social capital and empowerment. Evidence from the Uruguayan PANES. presentado en PEGNet, La Hay.

Amare, Y. 2002. Socio-economic dimensions of rural poverty in Ethiopia, a qualitative study of two highland communities in north Shewa. Journal of Ethiopian Studies, Vol. 35, No. 2 (December 2002), pp. 112-140

Antonopoulos, R. and Floro, M. 2005. Asset Ownership along Gender Lines: Evidence from Thailand. Working Paper \#418. Annandale-on-Hudson, NY: The Levy Economics Institute, Bard College.

Beegle, K., Frankenberg, E. and Thomas, D. 2001. Bargaining power within couples and use of prenatal and delivery care in Indonesia. Studies in Family Planning 32(2):130-146.

Bill and Melinda Gates Foundation. 2010. An annual report. CEO letter. Retrieved at www.gates foundation.org/annual report/ 2010.

Blattman, C., Green, E., Annan, J., Jamison, J., Bureau, C. F. P., Aryemo, F. and Segura, A. 2013. Building women's economic and social empowerment through enterprise: An experimental assessment of the women's income generating support (WINGS) Program in Uganda. AVSI and Innovations for Poverty Action, New Haven, CT.

Burt, R. 2000. The network structure of social capital. In: Robert Sutton and Barry Staw(Eds.).Research in Organizational Behavior. Greenwich, CT: JAI Press. pp. 345-423. 
Bwalya, G.M. and Akombelwa, M. 1999. Animal traction development and gender:experiences from Western Province, Zambia. In: Starkey, P. and Kaumbutho, P. (Eds.). Meeting the challenges of animal traction. A resource book of the Animal Traction Network for Eastern and Southern Africa (ATNESA), Harare, Zimbabwe. Intermediate Technology Publications, London. 326pp.

Doss, C.R. 2006. The effects of intrahousehold property ownership on expenditure patterns in Ghana. Journal of African Economies 15 (1): 149-80.

Forum for Agricultural Research in Africa (FARA) 2006. Framework for African Agricultural Productivity, Accra, Ghana: FARA.

Friedemann-Sanchez, G. 2006. Assets in intrahousehold bargaining among women workers in Colombia'scut-flower industry. Feminist Economics 12(1 - 2):247 -269.

Geetha, G. 2016. Asset possession status and work participation levels of farm women: A case study of sericulture. Global Journal of Sericulture and Cotton Production 1(1):001-004.

Grassi, J., Lamberg, J. and Huyer, S. 2015. Running out of time: The reduction of women's work burden in agricultural production. FAO, Rome, Italy.

Grootaert, C., Narayan, D., Jones, V. and Woolcock, M. 2004. Measuring social capital: An integrated questionnaire. World Bank Working Paper No. 18. World Bank, Washington, DC.

Guillén, M. 2013. Women entrepreneurs: Inspiring stories from emerging economies and developing countries. Routledge.

Hashemi, S.M, Schuler, S.R. and Riley, A.P. 1996. Rural credit programs and women's empowerment in Bangladesh. World Development 24(4):635-53.

ICRW/ULA. 2010. Inheritance laws, wills and women: Property rights and gender (A training tool kit). International Centre for Research on Women and Uganda Land Association. Retrieved from http://
www.icrw.org/files/publications/Gender. Accessed 11th January 2017. https:// www.icrw.org/wp-content/uploads/2016/ 10/Property-Rights-and-Gender-ATraining-Toolkit.pdf.

Jetti, A. 2006. Social capital: Strengthening women through networks. Strength Based Strategies -2006. www.strengthbased strategies.com/PAPERS/08\%20archanna\% 20jetti.pdf. Accessed $11^{\text {th }}$ January 2017.

Kumar, N. and Quisumbing, A.R. 2010. Evaluating the long-term impact of antipoverty interventions in rural Bangladesh. Chronic Poverty Research Centre. IFPRI.

Kumar, N. and Quisumbing, A. R. 2010. Does social capital build women's assets? The long-term impacts of group-based and individual dissemination of agricultural technology in Bangladesh (No. 97). International Food Policy Research Institute (IFPRI).

Larrea M. and Maldonado P. 2005. Circuito espacial de producción de la floricultura de exportación, Caso Ecuatoriano. Programa EcoSalud CEAS/CIID, Quito.

Lay, J. 2012. MDG achievements and policies in education and health: What has been learnt? Development Policy Review 30 (1): 67-85.

Nega, F., Mathijs, E., Deckers, J. and Tollens, E. 2010. Gender, social capital and empowerment in northern Ethiopia. University Library of Munich, Germany.

Nega, F., Mathis, E., Deckers, J. and Tollens, E. 2009. Gender, social capital, and empowerment in Northern Ethiopia. Munich Personal RePEc Archive Paper No. 24629. < http://mpra.ub.unimuenchen. de/24629/1/MPRA_paper_24629.pdf>. Accessed $11^{\text {th }}$ January 2017.

Njuki, J. and Mburu, S. 2013. Gender and ownership of livestock assetsinwomen, livestock ownership, and markets: Bridging the gender gap in Eastern and Southern Africa. Njuki, J. and Sanginga, P.C. (Eds.). Published by Routledge. ISBN: 978-0-41563928-6 (hbk). 
Njuki, J. and Sanginga, P. 2013. Gender and livestock: Key issues, challenges and opportunities: women, livestock ownership and markets, 1. Published by Routledge. ISBN: 978-0-415-63928-6.

Ogato, G.S., Boon, E.K. and Subramani, J. 2009. Improving access to productive resources and agricultural services through gender empowerment: A case study of three rural communities in Ambo District, Ethiopia. Journal of Human Ecology 27(2):85-100.

Oxfam, 2007. Biofueling poverty: why the EU renewable-fuel target may be disastrous for poor people. Oxfam Briefing Note, Oxford.

Quisumbing, A., Meinzen-Dick, R., Johnson, N., Njuki, J., Behrman J., Gilligan, D., Kovarik, C. and Manfre, C. 2014. Reducing the gender asset gap through agricultural development: A technical resource guide. IFPRI. http://www.ifpri.org/publication/ reducing-gender-asset-gap-throughagricultural-development. Accessed Accessed $11^{\text {th }}$ January 2017.

Quisumbing, A.R., Rubin, D., Manfre, C., Waithanji, E., van den Bold, M., Olney, D. and Meinzen-Dick, R. 2015. Gender, assets, and market-oriented agriculture: learning from high-value crop and livestock projects in Africa and Asia. Agriculture and Human Values 32(4):705-725.

Randriamaro, Zo 2008. Trade, poverty and women's economic empowerment in Sub-
Saharan Africa. United Nations Division for the Advancement of Women. United Nations. New York, USA.

Randriamaro, Z. 2009. Trade, poverty and women's economic empowerment in SubSaharan Africa. Division for the advancement of women, Department of Economic and Social Affairs, United Nations, New York, USA.

Starkey, P.H. and Faye, A. 1990. Animal traction for agricultural development. CTA.

UN-women, UNDP-UNEP PEI and World Bank. 2015. The cost of the gender gap in agricultural productivity in Malawi, Tanzania, and Uganda a joint product of UN Women, the United Nations Development Programme-United Nations Environment Programme PovertyEnvironment Initiative (UNDP-UNEP PEI) Africa, and the World Bank. http:// documents.worldbank.org/curated/en/ 847131467987832287/pdf/100234-WPPUBLIC-Box393225B-The-Cost-of-theGender-Gap-in-Agricultural-Productivityin-Malawi-Tanzania-and-Uganda.pdf. Accessed 11th January 2017.

White, J. 2010. Agro-fuels, enclosure and incorporation: gendered politics of oil palm expansion in a Dayak Hibun community in West Kalimantan. Working paper. International Institute of Social Studies, Rotterdam, the Netherlands. 